\title{
Assessing the Impact of Brexit on the European Union
}

\author{
Mihaela Neculita \\ NeculitaM@yahoo.fr \\ Daniela Ancuta Sarpe \\ daniela.ancuta.sarpe@gmail.com \\ Dunarea de Jos University of Galati, Romania
}

\begin{abstract}
Great Britain has always had a very interesting position, even a little strange, on the European Union. Between 2010 and 2015, Europe believed that Great Britain was entering an era of uncertainty, but this pertained to the failures of the states in Africa and Asia, rather than the status of Great Britain concerning Europe. The paradox is that despite the fact that Great Britain was entering an era of "uncertainty", its strategic review seemed very confident about its positioning and the nature of emerging threats. As a result, there were identified many more clarifications as to the British values, including the decision to join coalitions and alliances, similar to Switzerland. The paper proposes an integrated analysis of the United Kingdom and European situation by means of data provided by international institutions. The purpose of the paper is to evaluate the impact of Brexit on the European Union, and to estimate what will be the situation of the economies of the two entities after going out of the EU.
\end{abstract}

Key words: integration, disparities, commerce, contributions

JEL CODE: F02, F15, F36, P18

\section{Introduction}

The question of whether or not to join the single euro currency, and before that, other forms of union, has been one of the largest and most controversial issues contended with the British government in the last 40 years. This period follows the post-war era, when the European integration represented a series of similar debates for the successive prime ministers and their ministers. (Smith M., 2014)Down these decades until now, Great Britain displayed frequent hesitations, either its representatives arrived late at the EU parliamentary meetings, or they did not show at all, not even to show interest, while its continental neighbors embraced the ideal of a "closer union". All these decades of post-war hesitation have gained the status of "uncomfortable partner" for Great Britain and the successive embarrassment of British governments in front of the European economic integration, has rarely occurred without a fierce debate in the parliament and in the eyes of both the British and European public.

Indeed, the question of whether or not to stay in the European Union is a difficult topic in the evolution stage of the British economy, the Coalition government challenging not only the impact of the current economic difficulties in the Euro Zone on its attempts to revitalize Great Britain's economy, but also the internal debates within the parliamentary parties about the long territorial position of Great Britain within the European Union. Conventional wisdom often orbits around the idea that Britain's formal insistence upon the EU has been largely influenced by the internal political conditions that governments have had to act within the State, particularly: the pressure of Euroscepticism within the governing parties, fear to irritate a Eurosceptic electorate or the efforts of anti-European officials have had the purpose of ensuring that their authority is not reduced by the assignation of power to Brussels. (Buckledee S., 2018)

When looking for the embarrassing indecisions of the British governments towards the European Community in the 1950s and 1960s, commentators often reached very different 
conclusions and identified two main elements that supported the decisions made by British ministers on the country's position towards the EU:

- First, it was an ideology - namely, a strong and unabated belief, such as a preference to stand alone in relation to the Continental Europe.

- Secondly, it was what was called "pragmatism" - that is, the economic direction was the result of a cost - benefit analysis open to several options.

While the continental member states have aligned for the European economic integration offer, Great Britain has not. Instead, British Prime Minister John Major negotiated an "opt-out" that allowed Great Britain to avoid any sort of commitment to the EMU plans for the Future. Therebay, Great Britain has once again been regarded as an uncomfortable partner, and in particular that this decision has called in question the credibility of the partnership between EMU and Great Britain, and whether or not it will exit the EU. Along with the UK budget talking, Member States directed their attention to the completion of the European Single Market, while the UK was already thinking of a single UK market.

Great Britain remarked that EU monetary policy focuses only on price stability goals in a great measure, but it does not reach also the majority goals of countries to achieve maximum employment, or the trade level wanted.

Thus, it can be said that, although it was in the European Union, England enjoyed more sovereignty than the states in the area, and this outlook difference has led to deepening discrepancies among the EU states and decision-making powers, especially those of Great Britain. Great Britain might take the example of Switzerland, a developed state in Europe which does not belong to the European Union, but one never knows how it will outface the events.

The referendum on maintaining the United Kingdom in the European Union (Brexit) took place on June 23, 2016. After about a year, more precisely on March 29, 2017, the United Kingdom officially announced its decision to leave the European Union, by triggering the procedure provided in Article 50 of the Lisbon Treaty, a treaty that permits a member state to withdraw from the European Community block, and the paragraphs of Article 50 briefly explain the formalities to be followed for the State in question to go out of the EU (this Article 50 has never been invoked so far).

\section{Methodology}

In order to reach the objective of the present paper, numerous sources and materials have been appealed, focusing on data regarding European situation. This paper aims to develop an objective analysis of the current state of Great Britain and European Union by using data and statistics provided by international and European specialized institutions.

\section{Brexit}

The EU referendum in 2016 was a landmark in the external relations of Great Britain. The decision to stay or leave the European Union has caused a major debate in the United Kingdom with regard to spending, austerity, economic policy, immigration and identity. In the international context, Brexit is linked to Trump's coming to power and changing the economic poles in the world. It is not the first time that major global changes have taken place following the change of directions in the USA and Great Britain. The difference between the Thatcher Reagan and May - Trump cases is that May and Trump have the same political and economic orientation.

The transfer of the UK goods exports outside the EU reflects a change in the sources of economica growth, in particular Asia gaining ground. To a certain extent, other EU Member States have shifted their exports of goods from the intra-European market, but the effect has been most pronounced in Great Britain. Germany, despite intensive immigration, is 
maintaining a very low unemployment rate, since its comparative advantage consisted in technologically advanced products which, in fact, found a fairly significant market in developing countries, with a specialization that took advantage of globalization. Great Britain, instead, has specialized more in financial services.

The broadening of financial services industry, which creates very few but well remunerated jobs, has contributed to an increase in the income inequality, much more marked in the United Kingdom than in other parts of the European Union. Inequality contributed to combatting the frustration of globalization and so-called "institutions". Obviously, the decrease in 2008 of the financial market, which also continued in 2010, added nuclear fuel to this frustration, as the Great Britain economy entered an area of economic depression and is still striving to recover. Thus, despite the fact that the total percentage of immigrants in the United Kingdom is the same as in Germany, and despite the unemployment rate below 5\%, the anti-immigration sentiment has dominated and helped to achieve the Brexit campaign for victory ( Goncalves J.R., Rodrigues C.N., da Costa Cabral N., 2017). The fact that Great Britain is now relying more on access to world markets than on the EU internal competitive market has certainly contributed to the Brexit vote, as it has narrowed the sacrifice that the UK shoud have done for regaining control over trouble-spots such as immigration.

The general belief according to which Great Britain could provide privileged access to world markets through bilateral commitments, has helped more than if it did this as part of the EU. The fact that the EU has lost its second economic power, and that Great Britain has lost its largest trading partner is a de facto still valid. About $50 \%$ of all the UK trade is still taking place in the EU. Over the years, the EU joining has provided the UK with cheaper goods and services and a much richer platform for the UK exports. There is no doubt that Brexit will decrease commerce between Great Britain and the EU due to high tariffs imposed and non-tariff barriers.

While the United Kingdom will benefit from the fact that it would not make net contributions to the EU budget, for a long term it could lose additional integration savings. Eventually, Brexit will indeed result in loss of GDP and productivity for Great Britain and all EU countries, at least in the medium term. While, for a long term, the UK can benefit from bilateral agreements and less applicable legislation in the EU area, it is currently growing as one of the least regulated markets of products and services within the OECD.

Other uncertainties will be loans from banks, stock market volatility, the exchange rate of the pound and other short-term financial stabilities and other economic risks. Brexit has generally been seen as a chaos, a madness, for the international and continental European markets. Although it was initially hoped that Brexit would mean a reviewed relationship with the EU single market, this hope was moved up to 2019.

At the annual summit of the International Economic Forum in Davos, British Prime Minister Theresa May announced a hard exit of Great Britain from the EU. She closed up speculations with an extended negotiation within the single market (where Great Britain is already benefitting from exemptions that are advantageous to it). The Prime Minister wanted to end the membership of the single market as the EU restricts the UK's ability to negotiate bilateral agreements, namely with the USA, China, India, the Persian Gulf states, Australia and New Zealand. ( Concalves J.R., 2017) At global level, the European Union has a well-rounded position economically, and Great Britain, along with its exit, will have to regain its status, and its international weight, its role will be diminished without the European Union. It should be said that accession to the EU customs union is an important part, once the UK is outside the single market, as the EU caters for directly the cross-border tariff preferences. What are the economic advantages and disadvantages of Great Britain's exit from the EU? This topic is one of the most debated and discussed at the moment, and opinion is divided. These opinions can be centralized in a SWOT analysis, following to be explained the contingent and economic effects: (Oliver T., 2016) 
The Brexit SWOT analysis:

\section{Strengths}

- A decrease in the restrictions on small and large entrepreneurs. These will not compete with the EU producers;

- Sovereignty. As I explained above, Great Britain will have more sovereignty over its own economy but also over the drafting of economic policies.

\section{Opportunities}

- Will save more of the money invested. Great Britain has contributed $f 13$ billion to the EU, but has received aid of just $£$ 4.5billion. Thus leaving the EU will result in savings benefits.

- Implementation of their own economic policies and carrying out trade contracts without restrictions from the EU.

\section{Weaknesses}

- More than $50 \%$ of Great Britain goods are exported to the EU, and around $20 \%$ of UK imports come from several EU countries. Upon leaving the EU, Great Britain will have to recover the value of the goods it will lose.

- There will be problems with the place of work. More than 2 million people will have to find another job than carrying out trade.

- Multinationals having branches and subsidiaries in the EU countries will suffer. Many of them will have to withdraw their goods from the market.

- Great Britain will lose control over the Euro Zone, even though it was not part of it. It will no longer be able to protect the countries that were not part of the Euro Zone. London was the center of European trade in euro.

\section{Threats}

- The pound value dropped by $10 \%$, almost equal to its value in 1985 . The British banks have already lost more than 130 billion pounds.

- The attractiveness of the UK market will go down.

From the SWOT analysis, we can see the weight of the disadvantages of Britain leaving the EU, but, being a country known historically for its decision-making, Great Britain should manage the regulation of its market, now that it will also have sovereignty, and its main partner is a world superpower, namely the United States of America. Following Brexit, Great Britain also underwent a drop in its national GDP from \$ 3022 trillion in 2014 to \$2622.85 trillion in 2017, although, in 2018, Britain saw a 1.4\% increase in its GDP - compared to 2017. The United Kingdom exit from the EU did not affect the unemployment rate very much, on the contrary, it gradually decreased, from $4.7 \%$ in 2017 , to $3.8 \%$ in 2018 , according to statistics displayed by Eurostat and Bureau of Labor Statistics. The United Kingdom ougoing from the EU brings with it a multitude of consequences, the events being closely related one another concerning all the economic aspects of the case. The country exit from the EU brings an impact not only on itself and the European Union, but also on a global level. According to a study performed by the OECD, there is an evaluation of the possible near and far scenarios as regards the UK economy when leaving the EU, surely both in the short and long term, it is forecasted in the Great Britain GDP a $-3.3 \%$ fall off in the closest year 2020, -5.1\% in the best case and $-7.7 \%$ in the worst case in the following 10 years. (Tetlow G., Stojanovic A, 2019) The Brexit risk has begun to affect the financial market both in the Kingdom and in the Euro 
Zone. In order to better understand the Brexit effects on the financial market and the Euro Zone, we will present those listed above for 2015, 2016 and 2017.

Fig. 1. Comparison: The impact of Brexit on the evolution of the financial market in Great Britain and the Euro Zone (\%).

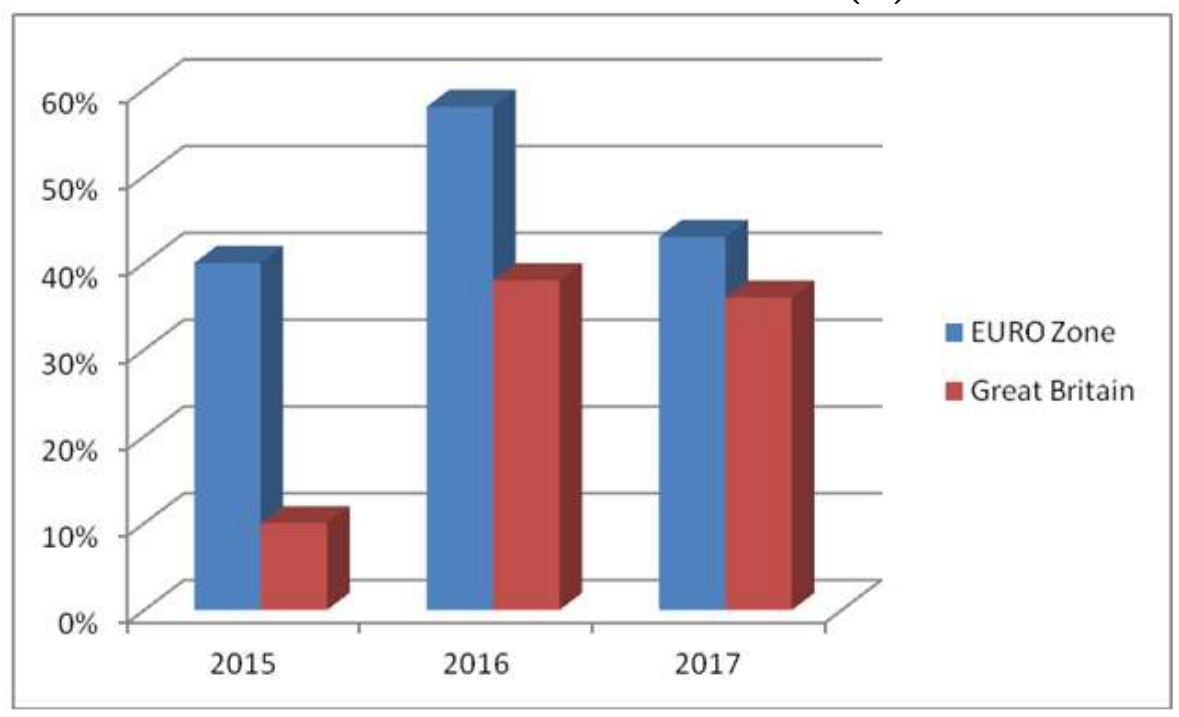

Source: OCDE, The Economic Consequences of Brexit, available at

http://www.oecd.org/economy/the-economic-consequences-of-brexit-a-taxing-decision.htm, accessed on 02.07.2019

From the figure above, we can realize the direct connection between Great Britain and the Euro Zone, it is specified in the SWOT analysis particularly that London was one of the trading centers of the euro circulation. The flow on the Eurozone financial market is directly proportional in evolution to the flow of the financial market in Great Britain, it only differs the percentage and the growth level of these two from a year to another.

The United Kingdom exit from the European Union also means a lot for the trade evolution. The Great Britain Treasury offers a multitude of scenarios, but these scenarios are also approached by other economists and university professors at international level. In April 2016, when the campaign for the United Kingdom exit of the EU was running, the Great Britain Treasury prepared a long-term report on the effects of the country's exit from the EU and what economic consequences it might result by its leaving. 3 possible scenarios have been included:

1. Economic openness and economic opportunities for the British would be narrowed;

2. Trade and investment flows would be reduced;

3. Labor productivity and GDP per capita would be shrunk, as costs will substantially exceed any possible benefit of leaving the EU.

After Brexit, multinationals will move a large part of their operations to other European capitals, two major European agencies will move to other EU member states, and about 30,000 jobs could disappear from the financial sector in London.

Some sectors of Great Britain will be greatly affected along with the permanent exit of the United Kingdom from the EU, mainly, there will be affected the export and import of goods, as well as businesses. The sectors that can have the largest impact on the export of goods are motor vehicles and electronic equipment, as well as the export of food. Motor vehicles, as a commodity, have the largest weight of trade between the United Kingdom and the EU, in as far as the United Kingdom is a major producer of motor vehicles and parts, as well as a significant market for the sale of motor vehicles (the second after Germany). The EU 
is the main export market for Great Britain, making up for $57.7 \%$ of the vehicle exports.( Velthuijen J.W., Bernard L, 2016) The services sector is the sector that will be the most affected by the Brexit, since the services industry accounts for almost $80 \%$ of the total British economy, according to an analysis of the HM Treasury of Great Britain. The impact on the trade of the EU-UK relationship will depend on the relationship between Great Britain and the EU following Brexit. Regardless of the country's options, Great Britain will have implicitly more costs than benefits. These costs can be defined largely by the market access (quotas and tariffs), the enhanced administrative burden (including customs formalities and VAT) and the rules underlying the borders that define the width of non-tariff barriers to trade. In 2017, one year after the referendum, the import and export partners changed drastically, the United States representing the partner no. 1 of the United Kingdom.

Fig. 2. Top 10 export partners of Great Britain (2018)

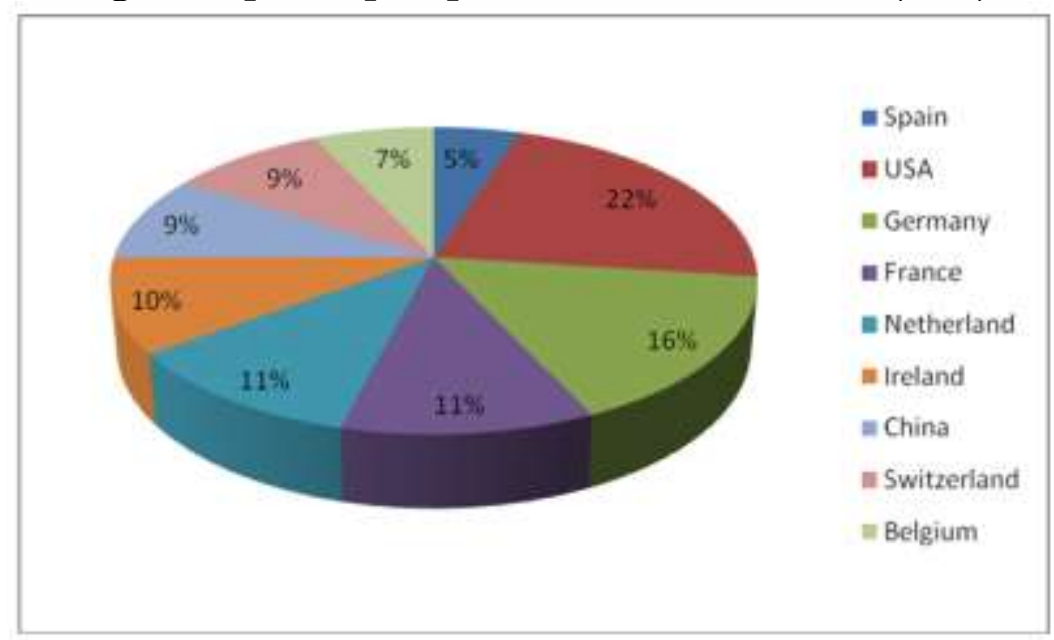

Source: Trading Economics, United Kingdom Exports By Country, available at https://tradingeconomics.com/united-kingdom/exports-by-country accessed on 02.07.2019.

From the above figure we can conclude that the weight of exports from the United Kingdom to the USA has increased considerably compared to the data provided by the Great Britain Treasury in 2016, when the Brexit referendum was still ongoing. Analyzing the postBrexit impact, this phenomenon will affect the tax regulation based on trade. The companies that transport products and services to the EU and import from various EU countries, have to pay taxes and duties in these countries. Upon transactions among companies, the products are often double taxed by the various tax authorities.( Goncalves J.R., Rodrigues C.N., da Costa Cabral N, 2017) Nevertheless, companies can avoid this double taxation by the EU Arbitration Convention. After leaving the EU, the United Kingdom will no longer participate in the EU tax legislation. It can be questioned whether Brexit would affect the EU Arbitration Convention, as it is a treaty strictly concluded between Member States. The global supply chain will be affected at the exit of the United Kingdom from the EU, since both Great Britain and the EU will have to rebalance their domestic economies, in the case of the EU it will occur faster, Great Britain will be more affected. At the import level, the EU occupies the top of the imports, followed by the rest of the countries. 
Fig. 3. The main import areas of the United Kingdom (2018)

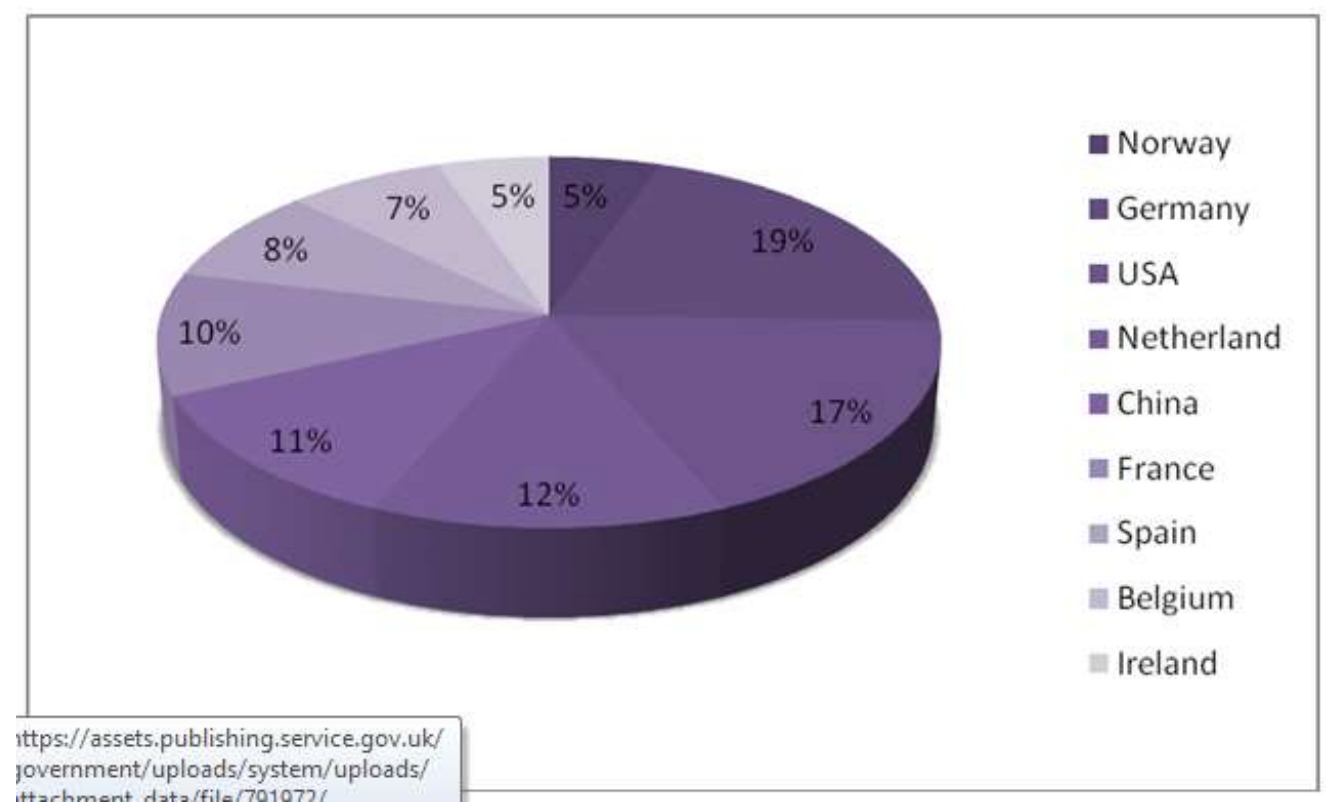

Htarhment data/fila/701073/Uploads/

Source: Department for International Trade, UK Trade in Numbers, available at https://assets.publishing.service.gov.uk/government/uploads/system/uploads/attachment d ata/file/791972/190402 UK Trade in Numbers full web version.pdf, accessed on 02.07.2019.

The EU Member States will have to see through their import and export partners, they will remain trading partners of the United Kingdom, but the weight of exports and imports of the EU-UK relationship will narrow substantially. The decrease in imports and exports of the United Kingdom to the European Union has steadily diminished, together with stregthening the relations between the United Kingdom and the United States.

Even though the EU is still remaining one of its most important trading partners, Great Britain has developed a number of external trading partners such as China, Hong Kong and Thailand in Asia, and the United States for both Americas. The major consequence of Brexit for companies and their export-import relations with EU27 Member States are the customs duties that will create additional costs for both parties. The solutions to reduce this effect have been proposed by many analysts, including members of the British Treasury and members of the European Commission, for the UK to enter into one of the 6 models partnerships with non-EU countries. The path that Britain will choose on this aspect is uncertain, and negotiations and the definitive exit will tell us more about the post-Brexit direction of the UK. A regional scenario predicts Scotland's desire for emancipation in order to gain independence from Britain, similarly to Catalonia in Spain, the difference being Scotland's desire to re-enter as an independent state in the European Union. This possibility is uncertain but given the 2014 Scottish referendum, this scenario could be repeated post-Brexit, with a Scottish referendum already planned in 2019, as a result of the UK leaving the EU. ( Curtice J, 2016) 
Fig. 4. Evolution of imports and exports between Great Britain and the EU

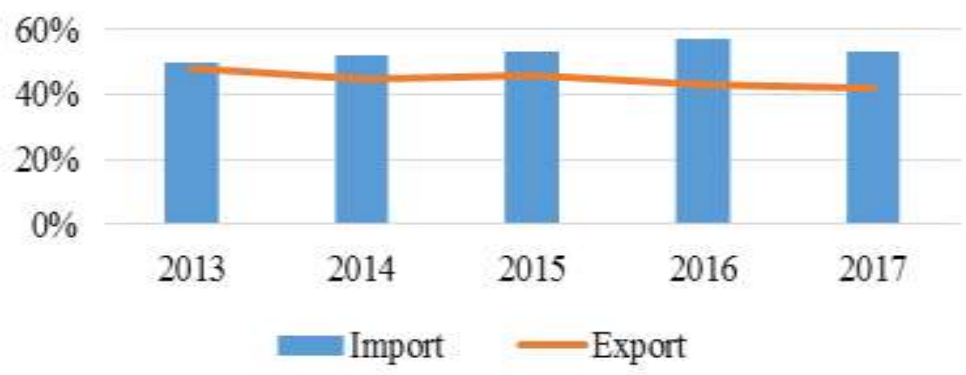

Source: Ward M., Statistics on UK-EU trade, House of Commons Library, Vol I. Nr. 7851, 2019, pp. 3.

Another reason for which the British parliament voted for leaving the European Union is that the United Kingdom paid quite large amounts to the European Union. These amounts were distributed to the other states to the end that help them in the development process, but the British state did not enjoy any benefit. In 2015 Great Britain contributed to the EU budget by 18 billion euros and received only 7.5 billion euros in the form of European funds, fact that is ranking it third after Germany and France in the top states with the most generous contributions to the EU budget.

Fig. 5. The contribution of Great Britain to the budget of the European Union 20102016
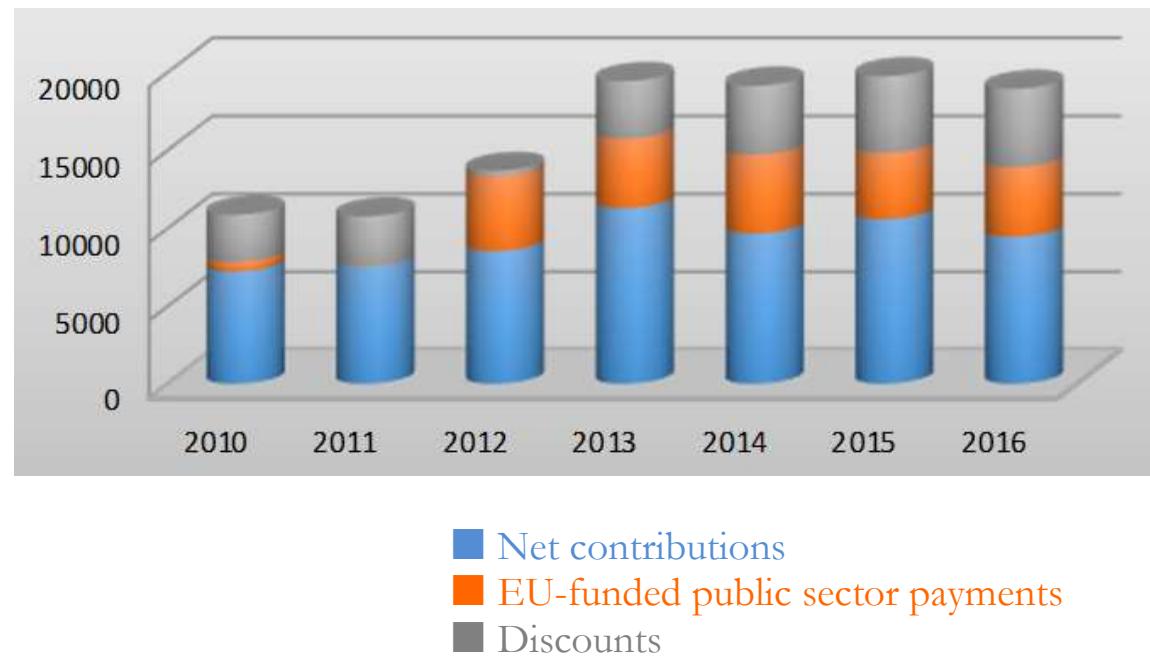

Source:https://visual.ons.gov.uk/the-uk-contribution-to-the-eu-budget

Immigration, according to Great Britain, would be a first advantage for the United Kingdom, in this case, the fact that it can forbid the free movement of persons within the European Union, due to the increase in the number of refugees in the Middle East. As advantages, we can also mention the right of the United Kingdom to fix its own taxes and duties by ignoring EU directions, as well as the fact that it will no longer have the obligation to pay membership fees to the European Union.

Not only will Great Britain would suffer following Brexit, but also the European Union will suffer as the decrease in the cross-border trade activities is adversely affecting economic growth throughout the Union and the rest of the world, and the other EU Member 
States must overall offset the payments that the United Kingdom made to the budget of the Union.

In the main, the EU can lose its influence in politics at military level, but also one of the first two European powers. Without the United Kingdom, the European Union will no longer be the most important player in the world economy except with great sacrifices from the highly developed countries such as France and Germany.

\begin{tabular}{|ccccccc|}
\hline Destination & $\begin{array}{c}\text { Tntra-EU } \\
\text { (bil.euro) }\end{array}$ & $\begin{array}{c}\text { Increase } \\
\%\end{array}$ & $\begin{array}{c}\text { Extra-EU } \\
\text { (bil.euro) }\end{array}$ & $\begin{array}{c}\text { Increase } \\
\%\end{array}$ & $\begin{array}{c}\text { Total } \\
\text { (mld.euro) }\end{array}$ & Increase \\
\hline Export & 161.9 & -5 & 171.6 & -17 & 333.5 & -12 \\
\hline Import & 266.7 & -5 & 262.3 & +8 & 529.0 & +1 \\
\hline Balance & -104.8 & -4 & -90.7 & +161 & -195.4 & +36 \\
\hline
\end{tabular}

Source: IndexMundi, accessed on 10.06.2018

The results of the foreign trade of Great Britain in 2016 show a relatively low integration with the EU economy and a half-half distribution of the trade flows carried out by the United Kingdom with EU and non-EU countries. It has been a $5 \%$ percent reduction of both intra-EU exports and imports, and the final balance being negative, exceeding the threshold of 100 billion euro. Neither in the case of extra-EU trade, the situation is not better, although the devaluation of the pound would have given the impression that it helps exports and discourages imports, so we have a negative balance of British trade, which increased by $36 \%$. Within the extra-EU relationship, exports decreased approximately $-17 \%$, and imports went up by $8 \%$, resulting in a deficit in the trade balance, a deficit that is twice higher compared to the previous year 2015.

For the EU trade, the United Kingdom exit from the EU will bring a significant improvement to the final output. In 2016, the EU exported goods amounting 1,511.2 billion euros, where Great Britain contributed only by $11 \%$ and imported 1,511.2 billion euros, to which the United Kingdom ticked $17 \%$, resulting in a small surplus of trade balance. For the non-EU trade of the 27 states without the UK would increase 5.5 times up to 110.8 billion euros, and if we add the United Kingdom we also add the 104.7 billion euro intra-EU deficit, and the EU trade balance reaches 215.7 billion euros.

\section{Conclusions}

The root of discrepancies in the EU is not recent and appeared during the post-war era. When the European political leaders urged the integration of the capital market and liberalized the cross-border banking system in the late 1980s and early 1990s, they failed to create joint institutions that would ensure financial stability. This premise awakened the skeptical spirit of British opponents regarding the effectiveness of EMU and, at the same time, the EU failed to control the discrepancies already present within the union.

What is the future of the EU and what are the proposals for diminishing the discrepancies within this union? As we have seen, from the statements of the participants in the EU economy and the EMU building-up, a well-functioning union must not neglect its existing problems. It has been proven that an enlargement could lead to creating even more regional disparities. (Beer S., 2016).

The Bank of England estimated that Brexit costs around 900 pounds (if we convert 1000 euros). Ultimately, Brexit will have a weakening effect on the economic strength of the Union, but it will have a really hard effect on the British economy. Even though they paid large enough amounts to support the EU budget, they did not think that such a move could 
bring them huge costs that they will bear after leaving the Union. In other words, this Brexit will be a lose-lose situation, but the one that will lose the most will be the British state.

Brexit can become a win-win negotiation through two possibilities, namely: the first would be if the United Kingdom decides not to leave the European Union, given that both parties could win, and the second if the participating parties would sign an agreement following the negotiations, thus the damages being smaller.

\section{References}

1. Beer S., Free the Country from a sinking ship, The Express, Vol. 1, nr. 21, 2016.

2. Buckledee S., The Language of Brexit: How Britain Talked Its Way Out of the European Union, Bloomsbury, Londra, 2018.

3. Concalves J.R., Brexit and the European Union in the Context of Globalization, CIDEEFF, Lisabona, 2017.

4. Curtice J., The Vote to leave EU: Litmus Test or Lightening Rod, British Social Attitudes, Vol. I, nr. 34, 201.

5. Goncalves J.R., Rodrigues C.N., da Costa Cabral N., After Brexit: Consequences of the European Union, Palgrave Macmillan, Lisabona, 2017.

6. Guzel E., Brexit: Implications for Britain and the EU, The World Research Centre, Londra, 2019.

7. Oliver T., Brexit: What happens next?, LSE Ideas, Londra, 2016.

8. Smith M., Policy-Making in the Treasury: Explaining Britain's chosen path on European Economic and Monetary Uniunon, Palgrave Macmillan, New York, 2014.

9. Tetlow G., Stojanovic A., Understanding the economic impact of Brexit, disponibil la bttp://bit.ly/321JdC5.

10. Velthuijen J.W., Bernard L., The impact of Brexit on (global) trade, Brexit Monitor, Vol. I, nr. 4, 2016.

11. Ward M., Statistics on UK-EU trade, House of Commons Library, Vol I. Nr. 7851, 2019.

\section{Publicații:}

***OCDE, The Economic Consequences of Brexit, available at http:/ / mwn.oecd.org/economy/the-economicconsequences-of-brexit-a-taxing-decision.btm, accessed on 02.07.2019

***Trading Economics, United Kingdom Exports By Country, available at https:/ / tradingeconomics.com/ united-kingdom/ exports-by-country accessed on 02.07.2019

***Department for International Trade, UK Trade in Numbers, available at bttps:/ / assets.publishing.service.gov.uk/government/ uploads/system/ uploads/attachment_data/file/ 791972 /190402_UK_Trade_in_Numbers_full_web_version.pdf, accessed on 02.07.2019.

***Ward M., Statistics on UK-EU trade, House of Commons Library, Vol I. Nr. 7851, 2019.

***bttp:/ / visual.ons.gov.uk/ the-uk-contribution-to-the-eu-budget

***bttps:/ / wow.indexmundi.com/ 